\title{
Drying Kinetics of Banana Peel
}

\section{Sravan Kumar K*}

Department of Food Engineering and Technology, Sant Longowal Institute of Engineering and Technology, Longowal, India

\begin{abstract}
Drying of blanched banana peel was carried out in tray dryer. The drying experiments were performed at two different temperatures and a constant air velocity of $0.5 \mathrm{~m} / \mathrm{s}$. To select a best model, five different thin layer drying models were fitted to experimental data. Nonlinear regression procedure was used to fit five different models. The models were compared with experimental data of banana peel drying at air temperature of $60^{\circ} \mathrm{C}$ and $70^{\circ} \mathrm{C}$. The best thin layer drying model was selected using the coefficient of determination $\left(\mathrm{R}^{2}\right)$, chi-square $\left(X^{2}\right)$ and Root Mean Square Error (RMSE). The highest value of $\mathrm{R}^{2}(0.99640$, $0.99652)$, the lowest of chi-square $\left(X^{2}\right)(0.000218,0.000231)$ and RMSE $(0.014778,0.015177)$ at temperature of $60^{\circ} \mathrm{C}$ and $70^{\circ} \mathrm{C}$ indicated that the Logarithmic and Henderson and Pabis model is the best mathematical model to describe the drying behaviour of banana peel.
\end{abstract}

Keywords: Drying kinetics; Banana peel; Mathematical modelling; Tray dryer

\section{Introduction}

Bananas (Musa sp.) are one of the most important tropical fruits consumed worldwide by people of all age groups. The nutritional and functional properties of bananas are known to provide good health. Nutritionally, bananas contain available carbohydrates which provide energy, vitamins $\mathrm{B}$ and $\mathrm{C}$, and significant amounts of potassium and magnesium and amino acids. The peels of banana also contain carbohydrates, proteins, and fiber in significant amounts, making it an ideal substrate for production of value added products [1,2]. Assuming that banana peels account for only $30 \%$ of the total fruit weight and have $20 \%$ dry matter, it contains minerals and various amino acids like aspartic acid, threonine, serine, glutamicacid, proline, glycine, alanine, cystine, valine, methionine, isoleucine, leucine, phenylalanine, lysine and arginine. To the best of our knowledge no past research was conducted to investigate the drying kinetics of banana peel in hot air drying [3-5]. In the view of the health promoting properties and high nutritional benefits of banana peel, the present study was carried out to observe the effect of different temperatures on drying characteristics of banana peel and to select the best mathematical model to observe the drying behavior of the banana peel.

\section{Materials and Methods}

\section{Drying experiment}

The peels of ripened bananas were collected from a vendor of local market. The peels was cut into the slices and blanched. The drying experiments carried out in a tray dryer at selected two air drying temperatures $\left(60^{\circ} \mathrm{C}\right.$ and $\left.70^{\circ} \mathrm{C}\right)$ to obtain the drying characteristics of banana peel. Air velocity was set at $0.5 \mathrm{~m} / \mathrm{s}$. When the dryer reached steady state conditions (i.e. when desired temperature was reached) the sliced banana peels were distributed onto the trays. Moisture loss was recorded at every 15 min intervals during drying $[1,6]$. Drying was continued until the moisture content of the sample reached to the equilibrium moisture content about $13-15 \%$ (wb). The drying was continued till weight became constant and experiments were conducted in duplicates.

\section{Mathematical modeling of drying curves}

The moisture ratio $(M R)$ of banana peel during drying experiments was calculated using the following Equation

$$
\mathrm{MR}=\left(\mathrm{M}-\mathrm{M}_{\mathrm{e}}\right) /\left(\mathrm{M}_{0}-\mathrm{M}_{\mathrm{e}}\right)
$$

Where $M, M o$, and $M_{e}$ are moisture content at any drying time, initial and equilibrium moisture content ( $\mathrm{kg}$ water $/ \mathrm{kg}$ dry matter), respectively.

Data obtained from the measurements of weight in a test was used for the analysis of drying kinetics of materials need to be changed first in the form of moisture content data. The moisture content was expressed as a percentage wet basis and then converted to moisture ratio $[7,8]$. The experimental drying data for banana peel were fitted to the exponential model thin layer drying models as shown in Table 1 by using non-linear regression analysis.

The regression analysis was performed using the STATISTICA computer program. In Non-linear regression, the parameters used to evaluate goodness of fit of the mathematical models to the experimental data are coefficient of determination $\left(\mathrm{R}^{2}\right)$ and the reduced chi-square $\left(X^{2}\right)$ was used for data analysis. The higher value for $\mathrm{R}^{2}$ and the lower values for $\chi^{2}$ and root mean square error analysis (RMSE) indicate the better fitness of model [9-12]. These parameters were calculated as follows:

$$
\mathrm{R}^{2}=1-\left[\frac{\sum_{i-1}^{N}\left(M_{\text {pre }, i}-M R \exp , i\right)^{2}}{\sum_{i-1}^{N}(\overline{M R} \text { pre }-M R} \operatorname{exp,i)^{2}}\right]
$$

Where, $\mathrm{n}=$ no. of unknown and $\mathrm{N}=$ Data point measured

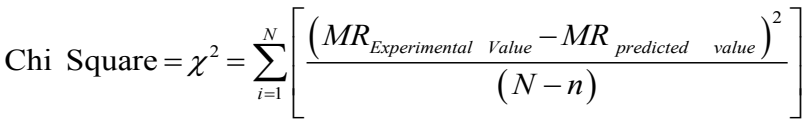

The mean relative deviation $\mathrm{E}(\%)$ is an absolute value that was used

*Corresonding author: Sravan Kumar K, Department of Food Engineering and Technology, Sant Longowal Institute of Engineering and Technology, Longowal, India, Tel: + 919886889673; E-mail: sravankumark39@yahoo.com

Received September 29, 2015; Accepted October 12, 2015; Published October 16, 2015

Citation: Kumar SK (2015) Drying Kinetics of Banana Peel. J Food Process Techno 6: 514. doi:10.4172/2157-7110.1000514

Copyright: (c) 2015 Kumar SK. This is an open-access article distributed under the terms of the Creative Commons Attribution License, which permits unrestricted use, distribution, and reproduction in any medium, provided the original author and source are credited. 


\begin{tabular}{|c|c|c|c|}
\hline S.NO & Model Name & Type & Reference \\
\hline 1 & Page & $M R=e x p\left(-k t^{n}\right)$ & Diamante and Munro [3] \\
\hline 2 & Newton & $M R=e x p(-k t)$ & Mujumdar [7] \\
\hline 3 & Wang and Singh & $M R=1+a t+b t^{2}$ & Wang and singh [10] \\
\hline 4 & Logarithamic & $M R=a \exp (-\mathrm{kt})+\mathrm{c}$ & Yagcioglu et al. [11] \\
\hline 5 & Henderson and Pabis & $M R=a$ exp(-kt) & Zhang and Litchfleld [12] \\
\hline
\end{tabular}

Table 1: List of models with references.

\begin{tabular}{|c|c|c|c|c|c|c|}
\hline Model & Temperature ${ }^{\circ} \mathrm{C}$ & Coefficient & $\begin{array}{c}\text { Coefficient Of } \\
\text { Determination }\left(\mathbf{R}^{2}\right)\end{array}$ & $\begin{array}{c}\text { Chi-Square } \\
\left(X^{2}\right)\end{array}$ & RSME & $\mathrm{E} \%$ \\
\hline \multirow[t]{2}{*}{ Newton } & 60 & $K=0.002258$ & 0.98510 & 0.000905 & 0.238748 & 7.727946 \\
\hline & 70 & $K=0.002427$ & 0.98289 & 0.001133 & 0.033654 & 5.213993 \\
\hline \multirow[t]{2}{*}{ Page } & 60 & $\begin{array}{l}\mathrm{K}=0.002494 \\
\mathrm{n}=0.983696\end{array}$ & 0.98518 & 0.009021 & 0.03002 & 7.262423 \\
\hline & 70 & $\begin{array}{l}\mathrm{K}=0.000929 \\
\mathrm{n}=1.161446\end{array}$ & 0.99268 & 0.000484 & 0.022007 & 3.371934 \\
\hline \multirow[t]{2}{*}{ Logarithmic } & 60 & $\begin{array}{l}K=0.003234 \\
a=0.981314 \\
c=0.113281\end{array}$ & 0.99640 & 0.000218 & 0.014778 & 2.795789 \\
\hline & 70 & $\begin{array}{l}K=0.002713 \\
a=1.091012 \\
c=0.002017\end{array}$ & 0.99652 & 0.000231 & 0.015179 & 2.497142 \\
\hline \multirow[t]{2}{*}{ Wang and Singh } & 60 & $\begin{array}{l}a=0.002006 \\
b=0.001001\end{array}$ & 0.98817 & 0.000718 & 0.026801 & 7.080818 \\
\hline & 70 & $\begin{array}{l}a=0.002047 \\
b=0.000012\end{array}$ & 0.99004 & 0.000659 & 0.025673 & 3.136054 \\
\hline \multirow[t]{2}{*}{ Henderson and pabis } & 60 & $\begin{array}{l}K=0.002347 \\
a=1.033488\end{array}$ & 0.98680 & 0.000802 & 0.028318 & 8.48627 \\
\hline & 70 & $\begin{array}{l}K=0.002703 \\
a=1.092349\end{array}$ & 0.99652 & 0.000231 & 0.015177 & 2.519419 \\
\hline
\end{tabular}

Table 2: The fitness of different models at different temperatures

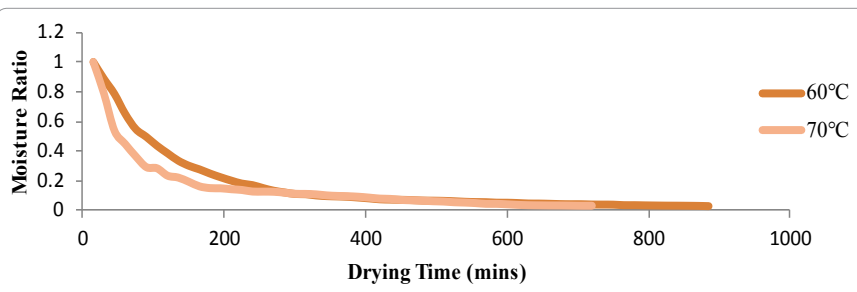

Figure 1: Moisture ratio versus drying time of banana peel at different temperatures.

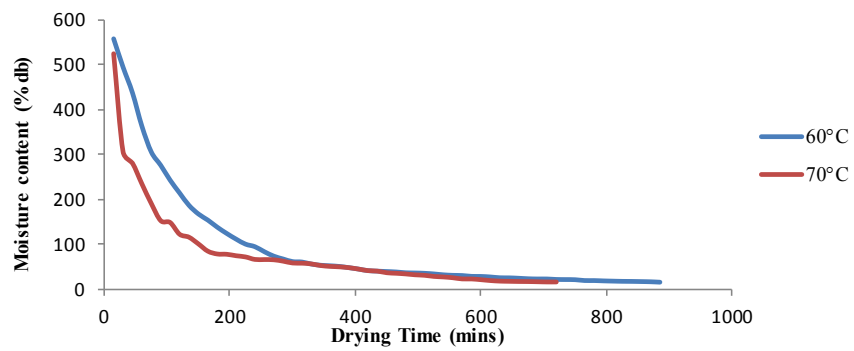

Figure 2: Drying curves of banana peel at different temperature.

because it gives a clear idea of the mean divergence of the estimated data from the measured data.

$$
\text { RMSE }=\text { Root mean square error }=\sum_{i=1}^{N}\left[\sqrt{\frac{\left(M R_{\text {Experimental value }}-M R_{\text {predicted value }}\right)^{2}}{N}}\right]
$$

The values of $\mathrm{E}$ less than 5.0 indicate an excellent fit, while values greater than 10 are indicative of a poor fit.

\section{Results and Discussion}

The drying process was stopped no change in the weight of sample of banana peel was observed. At this point moisture content was decreased. Moisture content data was converted to moisture ratio then fitted to the five thin layer drying models. Table 2 showing the results of fitting the experimental data to the thin layer drying models with best fitting model in bold type for temperature of $60^{\circ} \mathrm{C}$ and $70^{\circ} \mathrm{C}$. The drying rate decreased continuously throughout the drying period. The constant rate period was absent and the drying process of banana peel took place in falling rate period. The moisture ratio reduced exponentially as the drying time increased [4]. Continuous decrease in moisture ratio indicates that diffusion has governed the internal mass transfer. A higher drying air temperature decreased the moisture ratio faster due to the increase in air heat supply rate to banana peel and the acceleration of moisture migration [2].

From Table 2 it can be concluded that the best models for the temperature 60 and $70^{\circ} \mathrm{C}$ are Logarithmic and Henderson and Pabis with $0.99640,0.000218,0.014778$ and $0.99652,0.000231,0.015177$ values for R2, and RMSE respectively.

It can be seen that different initial moisture contents resulted in longer drying times for samples dried at 60 and $70^{\circ} \mathrm{C}$. Greater initial drying rate for the banana with the higher moisture content. Thus, higher initial moisture content in food resulted in a higher drying rate as expected. This causes rapid decrease in moisture content of the banana peel. High temperature accelerated the evaporation of moisture near the surface better than low temperature thus drying time could be reduced. The results of drying at $60^{\circ} \mathrm{C}$ agreed with the reports of Sabarez, Price and co-workers (1997) for drying plum of different initial moisture contents at $70^{\circ} \mathrm{C}$. Thus, a higher drying air temperature produced a higher drying rate and consequently the moisture ratio decreased (Figures 1 and 2). 


\section{Conclusion}

Drying using a hot-air chamber was tested on samples of banana peel. Drying kinetics curves of drying banana peel demonstrated that drying at $60^{\circ} \mathrm{C}$ and $70^{\circ} \mathrm{C}$ were the optimum values for drying banana peel with the appropriate equations using the logarithmic model and Henderson and pabis model with $\mathrm{R}^{2}$ of 0.9964 and $\mathrm{R}^{2}$ of 0.9965 . According to the results which showed the highest average values of $\mathrm{R}^{2}$ and the lowest average values of chi-square and RMSE, it can be stated that the logarithmic model and Henderson and pabis model was best fitted model to describe the drying characteristics of the samples.

\section{References}

1. Aghbashlo M, Kianmehr MH, Samimi Akhljahani H (2008) Influence of drying conditions on the effective moisture diffusivity energy of activation and energy consumption during the thin-layer drying of barberries fruit (Berberidaceae) Energy Conversion and Management 49: 2865-2871.

2. Demir V, Gunhan T, Yagcioglu AK, Degirmencioglu A (2004) Mathematical modeling and the determination of some quality parameters of air-dried bay leaves. Bio systems Engineering 88: 325-335.
3. Diamante LM, Munro PA (1993) Mathematical modeling of the thin layer solar drying of sweet potato slices. Solar Energy 51: 271-276.

4. Doymaz I (2007) Air-drying characteristics of tomatoes. Journal of Food Engineering 78: 1291-1297.

5. Doymaz I (2004) Convective air drying characteristics of thin layer carrots. Journal of Food Engineering 61: 359-364.

6. Henderson SM, Pabis S (1961) Grain drying theory. II: temperature effects on drying coefficients. Journal of Agricultural Engineering Research 6: 169-174.

7. Mujumdar AS (1987) Handbook of industrial drying. New York: Marcel Dekker.

8. Sabarez H, Price WE, Back PJ, Woolf LA (1997) Modelling the kinetics of drying of DAgen Plums (Prunus Domestica) Food Chemistry 60: 371-382.

9. Sarsavadia PN, Sawhney RL, Pangavhane DR, Singh SP (1999) Drying behaviour of brined onion slices. Journal of Food Engineering 40: 219-226.

10. Wang C, Singh RP (1978) A single layer drying equation for rough rice. ASAE, St. Joseph MI.

11. Yagcioglu A (1999) Drying technique of agricultural products. Ege University Faculty of Agriculture Publications, Bornova Izmir.

12. Zhang Q, Litchfleld JB (1991) An optimization of intermittent corn drying in a laboratory scale thin layer dryer. Drying Technology 9: 383-395. 